\title{
In vitro antioxidant properties and digestibility of chicken feather protein hydrolysates
}

\author{
1, * Oluba, O.M., ${ }^{2}$ Akpor, O.B., ${ }^{3}$ Alabi, O.O., ${ }^{3}$ Shoyombo, A.J., ${ }^{3}$ Adeyonu, A.G. and \\ ${ }^{4}$ Adebiyi, F.D. \\ ${ }^{1}$ Department of Biochemistry, Food Safety and Toxicology Research Unit, College of Pure and Applied \\ Sciences, Landmark University, P.M.B. 1001, Omu-Aran, Kwara State, Nigeria. \\ ${ }^{2}$ Department of Microbiology, Landmark University, P. M. B. 1001, Omu-Aran, Kwara State, Nigeria \\ ${ }^{3}$ Department of Agricultural Sciences, Landmark University, P. M. B. 1001, Omu-Aran, Kwara State, \\ Nigeria \\ ${ }^{4}$ Department of Chemical Sciences, Joseph Ayo Babalola University, Ikeji-Arakeji, Osun State, Nigeria
}

\section{Article history:}

Received: 10 December 2019

Received in revised form: 13

January 2020

Accepted: 15 January 2020

Available Online: 10

February 2020

\section{Keywords:}

Chicken feather,

Keratin,

Hydrolysate,

In vitro protein digestibility, Antioxidant activity

DOI:

https://doi.org/10.26656/fr.2017.4(4).402

\begin{abstract}
The in vitro antioxidant property and digestibility of chicken feather protein hydrolysate $(\mathrm{CFPH})$ were evaluated in this study. The antioxidant property of CFPH obtained following chemical treatment of chicken feather waste involving precipitation with various acids $\left(\mathrm{H}_{2} \mathrm{SO}_{4}, \mathrm{HNO}_{3}\right.$, TCA and $\left.\mathrm{HCl}\right)$ was determined via its scavenging action against 1,1-diphenyl-2-picrylhydrazyl (DPPH) radical, iron reduction power and metal ion chelating activity. Data obtained showed that $\mathrm{CFPH}_{\mathrm{HNO}}$ had the highest DPPH scavenging activity while $\mathrm{CFPH}_{\mathrm{TCA}}$ exhibited the highest ferric $\left(\mathrm{Fe}^{3+}\right)$ reduction potential. On the other hand, $\mathrm{CFPH}_{\mathrm{TCA}}, \mathrm{CFPH}_{\mathrm{H} 2 \mathrm{SO} 4}$ and $\mathrm{CFPH}_{\mathrm{HNO} 3}$ showed a similar capacity for $\mathrm{Fe}^{2+}$-chelation compared to $\mathrm{CFPH}_{\mathrm{H} 2 \mathrm{SO} 4}$ with the least chelating potential. The in vitro protein digestibility of the $\mathrm{CFPH}$ of the various acids ranged from $62.30 \pm 1.0 \%$ $\left(\mathrm{CFPH}_{\mathrm{HNO} 3}\right)$ to $73.10 \pm 1.3 \%\left(\mathrm{CFPH}_{\mathrm{TCA}}\right)$ and were significantly $(\mathrm{p}<0.05)$ higher compared to the raw feather $(23.80 \pm 0.5 \%)$. These results indicate that CFPH may be useful as antioxidants in animal feed formulations and also serve as additional source of essential nutrients in feeds.
\end{abstract}

\section{Introduction}

Feather wastes are often a source of environmental pollution. Thus, researches aimed at transforming these wastes into value-added products are warranted. The global annual contribution of solid waste in the form of feather is substantial. This is attributable to the rise in the global consumption of chickens (Jayathilakan et al., 2012; Boland et al., 2013). Feathers are very high in protein $(84 \%)$ but have a very low digestibility (Akpor et al., 2018). The principal protein in the feather is beta keratin, which is recalcitrant to enzymatic breakdown by animal, plant and numerous microorganisms (Onifade et al., 1998; Zaghloul et al., 2011), hence contributing to the low biodegradability of feathers. This low decomposition processes most often result in environmental pollution. Therefore, with the recent realities on the effects of climate change, and the call for more rigid regulations on refuse and waste disposal, new methods for handling feather wastes are required.

Recently, there has been an increased interest in the search for natural antioxidants with less potential health hazard as an alternative to synthetic antioxidants. Consequently, research on the antioxidant property of agro-wastes has gained increased interest. Antioxidants in foods, in addition to their importance in animal health, are vital in the prevention of food deterioration (Fawolo et al., 2014). Auto-oxidation process has been implicated in food deterioration (Carocho and Ferreira, 2013). The consumption of oxidized foods confers serious health challenges to the consumer and has been implicated in the pathogenesis of diseases such as ageing, cancer, diabetes, hypertension (Kanner, 2007). Bioactive peptides with high antioxidant activity have been extracted from enzymatically hydrolyzed feather keratin. Keratinous hydrolysates have been reported to demonstrate antioxidant activity especially in comparison to collagenous hydrolysates (Lasekan et al., 2013). A report by Fakhfakh et al. (2011) showed that chicken feather hydrolysate obtained following the fermentation of feathers with the bacterium Bacillus pumilus A1 exhibited DPPH radical scavenging activity 
of $0.3 \mathrm{mg} / \mathrm{mL}$ after $48 \mathrm{hrs}$. In this context, the conversion of feather biomass into feather protein hydrolysates with potent antioxidant property would be an interesting possibility.

The choice of method for the hydrolysis of proteins most often is dependent on the source of the protein in question. Keratin from hair, horns, feathers, beaks or wool is most often hydrolyzed by treatment with acid, alkalis or microbial keratinases (Hou et al., 2017). Therefore, the use of acids or alkalis in the hydrolysis of feather biomass is a very typical method used in the biomass transformation process (Tesfaye et al., 2017; Akpor et al., 2019). Such treatments have been found to also improve the solubility and susceptibility of feather protein to the action of proteolytic enzymes (Steiner et al., 1983). Thus, chemical hydrolysis of chicken feather wastes using alkalis remains a viable option in the enhancement of the digestibility of feather either as feedstuff and food supplements. Information on the bioactivity of chemically hydrolyzed feather protein hydrolysate is scanty. Therefore, this study was designed to evaluate the in vitro antioxidant property and digestibility of alkaline-hydrolyzed chicken feather hydrolysate.

\section{Materials and methods}

\subsection{Chicken feather waste}

White-colored chicken feather waste was collected from the slaughterhouse of the Landmark University Commercial Farm (Omu-Aran, Nigeria).

\subsection{Preparation of chicken feather protein hydrolysate}

Chicken feathers were washed with detergent and $5 \%$ hypochlorite solution, rinsed thoroughly with a copious amount of water, and sun-dried. The dried feathers were ground into powder using a mechanical grinder. A total of $300 \mathrm{~g}$ of the powdered feathers was weighed and soaked in acetone for $6 \mathrm{hrs}$ and then dried before being extracted with a $1 \mathrm{M} \mathrm{NaOH}$ solution (wt/ vol, $3: 10$ ) for $6 \mathrm{hrs}$ at room temperature with constant stirring. Thereafter, the resulting mixture was filtered using a clean dry muslin cloth to remove unhydrolyzed feathers. The hydrolyzed feather solution was divided into four portions. The $\mathrm{pH}$ of each of the hydrolyzed feather solution was adjusted to neutral separately with $10 \%$ trichloroacetic acid $\left(\mathrm{CFPH}_{\mathrm{TCA}}\right), 1 \mathrm{M} \mathrm{H}_{2} \mathrm{SO}_{4}$ (as $\mathrm{CFPH}_{\mathrm{H} 2 \mathrm{SO}}$ ), $1 \mathrm{M} \mathrm{HNO}_{3}\left(\right.$ as $\mathrm{CFPH}_{\mathrm{HNO} 3}$ ) and $1 \mathrm{M} \mathrm{HCl}$ (as $\mathrm{CFPH}_{\mathrm{HCl}}$ ) respectively. The resulting mixture was centrifuged $(3000 \times g)$ at $4^{\circ} \mathrm{C}$ for 10 mins discarding the supernatant thereafter. The obtained CFPH was dialyzed with cellulose tubes immersed in distilled water for 72 hrs while changing the water 3 times within $24 \mathrm{hrs}$. The dialyzed feather hydrolysate was freeze-dried to obtain chicken feather protein hydrolysate powder which was stored in a dried airtight container and at $4^{\circ} \mathrm{C}$ until it was required for further analysis. The procedures for the preparation of CFPH is shown in Figure 1.

\subsection{Compositional analysis}

The unprocessed chicken feathers and the respective acid CFPHs were analyzed for crude protein by the Kjeldahl method (Zhu et al., 2010). Similarly, amino acid profile for both raw chicken feather and the respective acid $\mathrm{CFPH}$ was determined following hydrolysis with $6 \mathrm{M} \mathrm{HCl}$ (containing phenol) for $24 \mathrm{hrs}$ at $115^{\circ} \mathrm{C}$ in glass tubes sealed under vacuum according to the method of Ravindran et al. (2005). Each analysis was carried out in triplicates.

\subsection{Antioxidant assays}

\subsubsection{DPPH scavenging activity}

The scavenging activity of the respective acid CFPH against 1,1-diphenyl-2-picrylhydrazyl (DPPH) radical was estimated following the method of Bersuder et al. (1998) using butylated hydroxylanisole (BHA) as standard. Briefly, for the respective acid $1 \mathrm{~mL}$ of CFPH

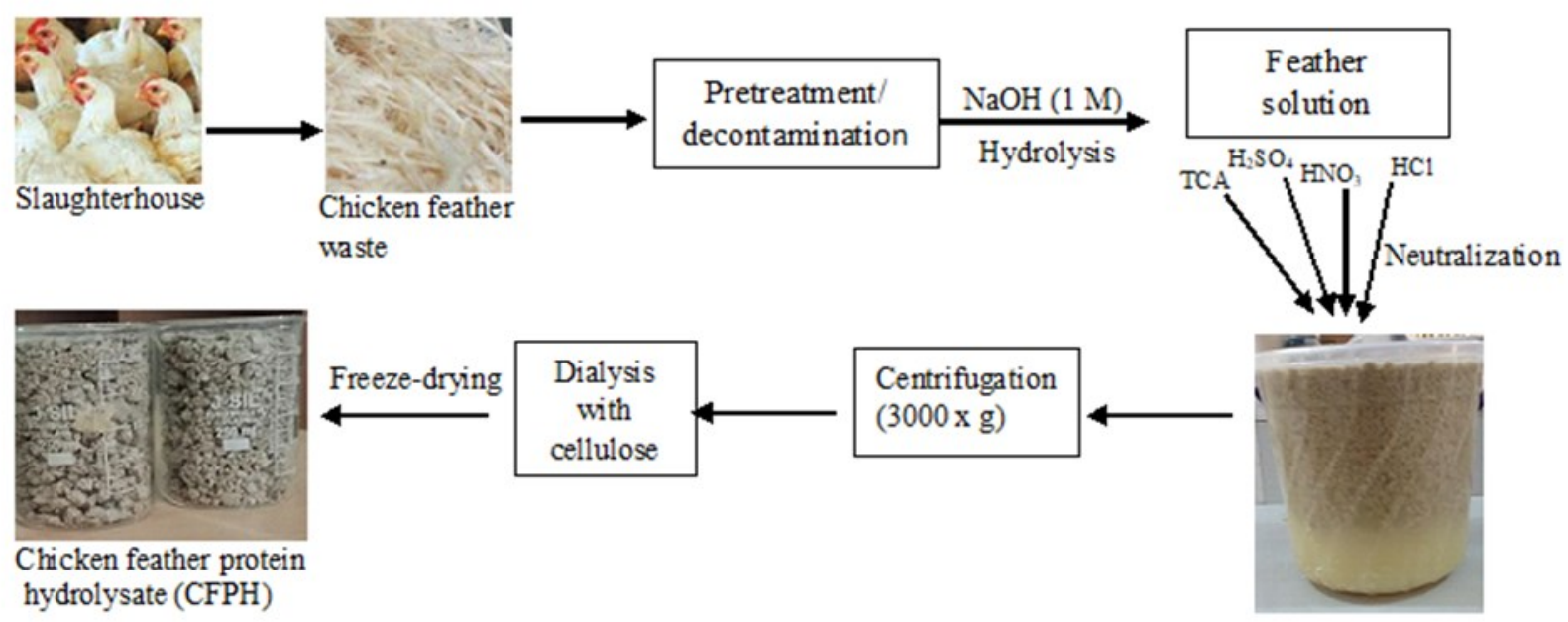

Figure 1. Flow chart for the extraction of chicken feather protein hydrolysate from waste feathers $(\mathrm{CFPH})$ 
corresponding to different protein concentrations $(0.2-$ $1.0 \mathrm{mg} / \mathrm{mL}$ ) was added to $0.1 \mathrm{~mL}$ DPPH in ethanol. The resulting mixture was vortexed for $1 \mathrm{hr}$ and kept at $25^{\circ} \mathrm{C}$ in the dark. Thereafter, the absorbance of the reaction mixture was taken at $517 \mathrm{~nm}$. A blank in which distilled water was added in lieu of sample was run in the same way. A sample control in which ethanol was added in lieu of DPPH was also carried out for the respective $\mathrm{CFPH}$. Each determination was carried out in triplicate. The DPPH radical scavenging activity was calculated in percentage according to the formula:

Scavenging activity $(\%)=1-\frac{\text { Asample }- \text { Asample control }}{\text { Ahlank }} \times 100$

2.4.2 $\mathrm{Fe}^{3+}$ reducing activity

The $\mathrm{Fe}^{3+}$ reducing potential of the respective CFPH was estimated according to the method Yindirim et al. (2001). To a $2 \mathrm{~mL}$ of the respective CFPH at different protein concentrations $(0.1-1.0 \mathrm{mg} / \mathrm{mL}) 2 \mathrm{~mL}$ phosphate buffer $(0.2 \mathrm{mM}$, pH 6.6) and $2 \mathrm{~mL}$ potassium ferricyanide $(1 \%)$ were added. The resulting mixture was incubated at $50^{\circ} \mathrm{C}$ for 20 mins before adding $2 \mathrm{~mL}$ of trichloroacetic acid (TCA, 10\%) and then centrifuged at $1500 \mathrm{x} g$ for 10 mins. To a $2 \mathrm{~mL}$ of the supernatant $2 \mathrm{~mL}$ of distilled water and $0.4 \mathrm{~mL}$ of ferric chloride (1\%) were added. After 10 mins, the absorbance of the solution was taken at $700 \mathrm{~nm}$. For the control, an equivalent volume of distilled water was added instead of the sample. Analysis for each sample was carried out in triplicates.

\subsubsection{Metal $\left(\mathrm{Fe}^{2+}\right)$ chelating activity}

The respective acid CFPH were evaluated for ironchelating activity according to the methods described by Ebrahimzadeh et al. (2008). To $1 \mathrm{~mL}$ of the respective $\mathrm{CFPH}$ at different protein concentrations $(0.2-1.0 \mathrm{mg} /$ $\mathrm{mL}), 3.7 \mathrm{~mL}$ distilled water was added. Thereafter, 100 $\mu \mathrm{L}$ of $2 \mathrm{mM} \mathrm{FeCl}_{2}$ was added. After 3 mins, the reaction was stopped by adding $200 \mu \mathrm{L}$ of $5 \mathrm{mM}$ ferrozine solution. The resulting mixture was shaken vigorously and left at $37^{\circ} \mathrm{C}$ for 10 mins before reading the absorbance at $562 \mathrm{~nm}$. In the same way, a blank was run using distilled water in lieu of the sample. Analysis for each sample was done in triplicates. The iron-chelating activity was calculated in percentage according to the formula:

$$
\text { Iron chelating activity }(\%)=1-\frac{\text { Asample }- \text { Asample control }}{\text { Ahlank }} \times 100
$$

\subsubsection{Determination of in vitro protein digestibility}

The in vitro protein digestibility of the respective CFPH was evaluated using the multi-enzyme solution according to the method described by Manjula and John (1991) with little modifications. A known weight of the respective $\mathrm{CFPH}$ containing $16 \mathrm{mg}$ nitrogen was digested with1 mg pepsin dissolved in $15 \mathrm{~mL}$ of $\mathrm{HCl}$
$(0.1 \mathrm{M})$ at room temperature for $2 \mathrm{hrs}$. The reaction was inhibited by adding $15 \mathrm{~mL}$ TCA (10\%). The resulting mixture was filtered using Whatman No. 1 filter paper. Thereafter the nitrogen content of the TCA-soluble fraction was determined using the micro-Kjeldahl method and the in vitro protein digestibility was estimated using the equation:

In vitro protein digestibility $(\%)=\frac{\text { Content of proteln released upon the digestion of } 1 \mathrm{~g} \text { of sample }}{\text { Content of } \mathrm{I} \text { proteln of } \mathrm{I} \mathrm{g} \text { of sample before digestion }}$

\subsection{Statistical analyses}

The results are presented as the means \pm SD of triplicate biological assays. The statistical analysis was by One-way analysis of variance (ANOVA) followed by Turkey's Multiple Comparison using SPSS version 20. $P<0.05$ was considered significant. All graphs were plotted using Graph Pad Prism.

\section{Results}

\subsection{Proximate composition}

The crude protein content of CFPH had significantly higher crude protein $(88.6 \pm 0.04 \%)$ compared with the raw feather $(71.8 \pm 0.1 \%)$. There was a significant decrease in methionine, lysine, cysteine and histidine level in the CFPH compared to the raw chicken feather (Table 1).

\subsection{Antioxidant activity}

\subsubsection{DPPH scavenging activity}

The DPPH scavenging activity of the respective acid CFPH was observed to be concentration dependent. $\mathrm{CFPH}_{\mathrm{HNO} 3}$ exhibited the highest scavenging activity, followed by $\mathrm{CFPH}_{\mathrm{H} 2 \mathrm{SO} 4}$ while $\mathrm{CFPH}_{\mathrm{HCl}}$ showed the least activity (Figure 2).

\subsubsection{Reducing power assay}

$\mathrm{CFPH}_{\mathrm{TCA}}$ showed significantly higher ferric reduction potential across all concentrations compared to CFPH of the other acids. No significant difference in ferric reduction activity was observed between $\mathrm{CFPH}_{\mathrm{H} 2 \mathrm{SO} 4}, \mathrm{CFPH}_{\mathrm{HNO} 3}$ and $\mathrm{CFPH}_{\mathrm{HCl}}$ (Figure 3 ).

\subsubsection{Metal chelating activity}

The metal chelation activity of the respective acid CFPH was observed to be concentration dependent. No significant difference in iron-chelating activity was observed between $\mathrm{CFPH}_{\mathrm{TCA}}, \mathrm{CFPH}_{\mathrm{H} 2 \mathrm{SO} 4}$ and $\mathrm{CFPH}_{\mathrm{HNO} 3}$ but the CFPH of the 3 acids exhibited significantly ironchelating activity compared to $\mathrm{CFPH}_{\mathrm{HCl}}$ (Figure 4).

\subsubsection{In vitro digestibility}

The in vitro protein digestibility recorded for the hydrolysates showed that $\mathrm{CFPH}_{\mathrm{HCl}}>\mathrm{CFPH}_{\mathrm{HNO}}>$ 
Table 1. Chemical composition of raw chicken feather and the respective acid chicken feather protein hydrolysate (CFPH)

\begin{tabular}{lcccccc}
\hline & \multicolumn{5}{c}{ Ratio of fish meal to chicken feather protein hydrolysate } \\
\cline { 2 - 6 } & $100: 0$ & $80: 20$ & $60: 40$ & $40: 60$ & $20: 80$ & $0: 100$ \\
\hline Proximate composition (\%) & \multicolumn{7}{c}{} & & & \\
\hline Moisture & $7.3 \pm 1.0^{\mathrm{a}}$ & $9.0 \pm 2.0$ & $9.0 \pm 1.5$ & $9.0 \pm 1.3$ & $8.0 \pm 0.3$ & $9.0 \pm 0.7$ \\
Crude protein & $24.42 \pm 1.1^{\mathrm{a}}$ & $23.83 \pm 0.2^{\mathrm{a}}$ & $21.12 \pm 0.5$ & $20.96 \pm 1.2$ & $22.16 \pm 0.4$ & $23.86 \pm 0.0$ \\
Nitrogen-free extract $^{1}$ & $55.88 \pm 5.2^{\mathrm{a}}$ & $57.17 \pm 3.8^{\mathrm{a}}$ & $61.08 \pm 5.5^{\mathrm{a}}$ & $61.14 \pm 2.1^{\mathrm{a}}$ & $60.34 \pm 5.8^{\mathrm{a}}$ & $58.04 \pm 4.9^{\mathrm{a}}$ \\
Energy (kcal/100 g) & $358.4^{\mathrm{a}}$ & $346.5^{\mathrm{a}}$ & $349.5^{\mathrm{a}}$ & $349.1^{\mathrm{a}}$ & $349.8^{\mathrm{a}}$ & $343.8^{\mathrm{a}}$ \\
\hline Amino Acid Composition & \multicolumn{7}{c}{} & & & \\
\hline Lysine & $2.56^{\mathrm{a}}$ & $0.58^{\mathrm{b}}$ & $0.42^{\mathrm{b}, \mathrm{c}}$ & $0.33^{\mathrm{c}}$ & $0.33^{\mathrm{c}}$ & $0.31^{\mathrm{c}}$ \\
Threonine & 4.50 & 4.52 & 4.38 & 4.35 & 4.35 & 4.33 \\
Cysteine & $1.02^{\mathrm{a}}$ & $2.85^{\mathrm{a}}$ & $3.27^{\mathrm{b}}$ & $3.33^{\mathrm{b}}$ & $3.50^{\mathrm{b}}$ & $3.30^{\mathrm{b}}$ \\
Leucine & 6.88 & 6.55 & 7.61 & 7.53 & 7.83 & 7.82 \\
Isoleucine & 4.58 & 4.55 & 4.38 & 4.53 & 4.52 & 4.50 \\
Tryptophan & $2.56^{\mathrm{a}}$ & $1.01^{\mathrm{b}}$ & $0.62^{\mathrm{c}}$ & $0.55^{\mathrm{c}}$ & $0.48^{\mathrm{c}}$ & $0.48^{\mathrm{c}}$ \\
Methionine & $2.79^{\mathrm{a}}$ & $1.53^{\mathrm{b}}$ & $0.88^{\mathrm{c}}$ & $0.85^{\mathrm{c}}$ & $0.81^{\mathrm{c}}$ & $0.77^{\mathrm{c}}$ \\
Phenylalanine & 5.53 & 5.50 & 5.33 & 5.35 & 5.30 & 5.22 \\
Histidine & $3.03^{\mathrm{a}}$ & $2.82^{\mathrm{a}}$ & $0.73^{\mathrm{b}}$ & $0.65^{\mathrm{b}}$ & $0.62^{\mathrm{b}}$ & $0.63^{\mathrm{b}}$ \\
Valine & 9.55 & 9.33 & 9.05 & 9.03 & 8.93 & 8.88 \\
Arginine & 4.83 & 4.85 & 4.55 & 4.33 & 4.55 & 4.52 \\
Serine & 12.58 & 12.80 & 12.85 & 13.20 & 13.20 & 13.05 \\
Glycine & 10.20 & 10.21 & 9.55 & 9.80 & 9.85 & 9.85 \\
\hline
\end{tabular}

Values are given as mean \pm SD of triplicate determinations. Values in the same row carrying different superscripts are significant $(\mathrm{P}<0.05)$.

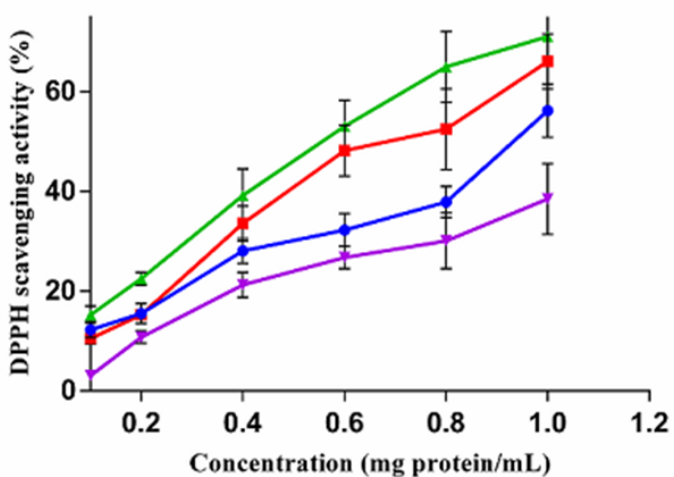

Figure 2. DPPH scavenging activity of the respective acid $\mathrm{CFPH}$ at different protein concentrations. Values are means \pm SD of three determinations. Note: CFPH, chicken feather protein hydrolysate

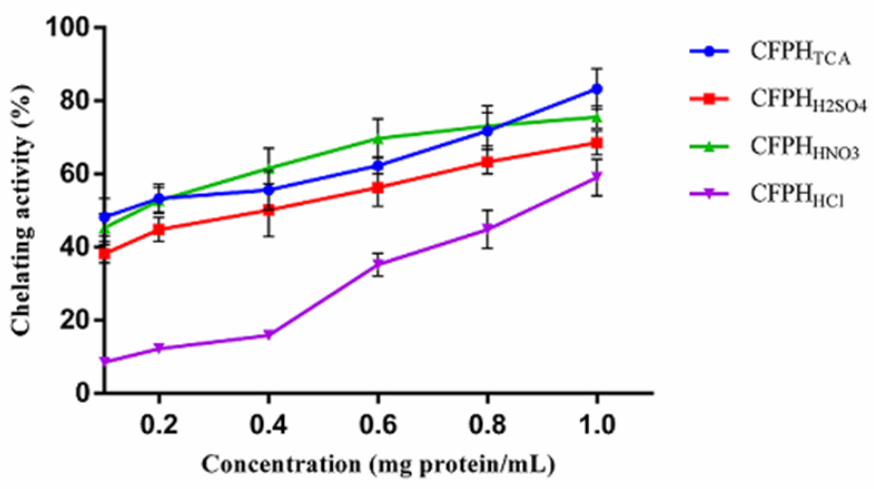

Figure 4. Iron chelating activity of the respective acid CFPH at different protein concentrations. Values are means \pm SD of three determinations. Note: $\mathrm{CFPH}$, chicken feather protein hydrolysate

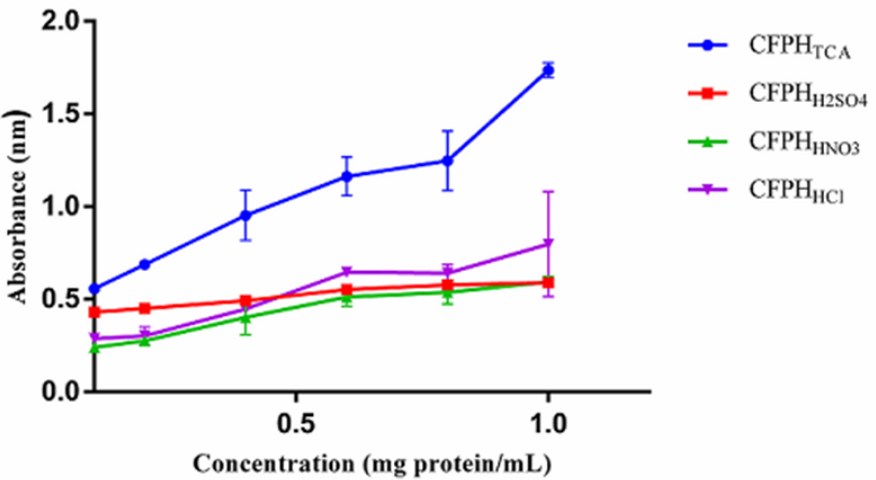

Figure 3. Ferric reducing activity of the respective CFPH at different protein concentrations. Values are means \pm SD of three determinations. Note: $\mathrm{CFPH}$, chicken feather protein hydrolysate

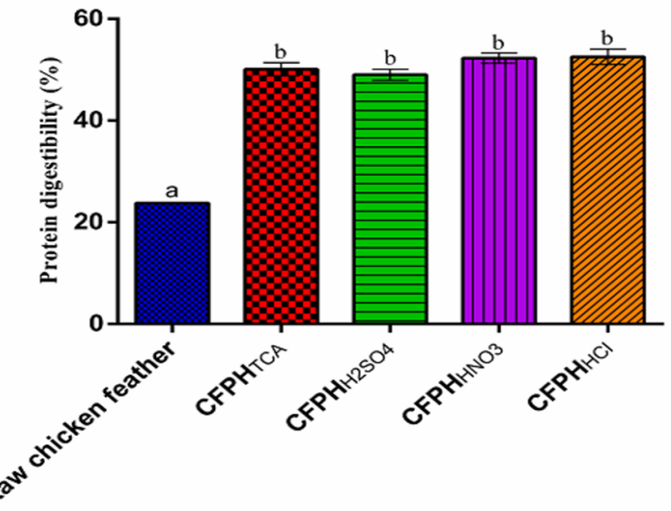

Figure 5. In vitro protein digestibility of the different chicken feather protein hydrolysates. Values are means \pm SD of three determinations. Note: CFPH, chicken feather protein hydrolysate 
$\mathrm{CFPH}_{\mathrm{TCA}}>\mathrm{CFPH}_{\mathrm{H} 2 \mathrm{SO} 4}$ with values $52.5 \%, 52.3 \%$, $50.1 \%$ and $49.0 \%$ respectively. The differences in digestibility across the different hydrolysates were not significant $(p>0.05)$ but were significantly higher than that of the raw feather (Figure 5).

\section{Discussion}

In the present study, CFPH was demonstrated to show antioxidant activity in vitro through its scavenging action against $\mathrm{DPPH}, \mathrm{Fe}^{3+}$ reduction potential and ironchelating activity. These results agree with the report of a study Je et al. (2007) in which protein hydrolysate obtained from bullfrog muscle was reported to demonstrate antioxidant activity using DPPH scavenging and ferrozine assays. Similarly, Chan et al. (1994) showed that meat dipeptide carnosine antioxidant action was as a result of its chelation activity against prooxidant metals. In addition, hydrolysate obtained from porcine myofibrillar via enzymatic hydrolysis was reported to possess excellent DPPH scavenging and metal chelation activities (Saiga et al., 2003). The antioxidant activity of protein hydrolysate has been attributed to the action of peptides (Gomez-Guillen et al., 2011). Chemical or enzymatic hydrolysis disrupts protein tertiary structure thus enhancing the solvation properties of its amino acid residues and consequently its antioxidant activity. The resulting peptides protein hydrolysis have been demonstrated to show enhanced antioxidant activity compared to intact proteins. The excellent antioxidant potential of proteinaceous supplements has enabled their inclusion in foods to retard or inhibit the oxidation of foods. The antioxidant action of free of protein hydrolysates involves such mechanisms as deactivation of reactive oxygen species, reduction of hydroperoxides, chelation of prooxidant metallic ions, and changes in the physical properties of food systems (Elias et al., 2008; Tang et al., 2009).

The high amounts of sulfur-containing amino acids, cysteine have been indicated to account for the antioxidant activity of feather keratin. For instance, in a study by Ohba et al. (2003), enzymatic hydrolysate obtained from a mixture of horn, hoof and chicken feather was demonstrated to show enhanced antioxidant activity. In another related study, Fakhfakh et al. (2013) reported also that protein hydrolysate obtained from chicken feather fermented with the bacterium Bacillus pumilus A1 showed strong antioxidant activity.

Data from this study revealed that the use of alkalis in the hydrolysis of chicken feathers to obtain CFPH significantly improved the digestibility of feather in vitro. This is in agreement with the report of Steiner et al. (1983) in which feathers treated with varying concentrations of $\mathrm{NaOH}$ or $\mathrm{H}_{3} \mathrm{PO}_{4}$ showed improvement in vitro pepsin digestibility. In a related study by Papdopoulos (1985) broiler feathers with various concentrations of $\mathrm{NaOH}$ or maxatase showed increased solubility and susceptibility to digestion by proteolytic enzymes. It could thus be argued that treatment with $\mathrm{NaOH}$ or enzyme weakens and exposes the disulfide linkages in feather keratin backbone thus increasing the solvation property of its amino acid residues culminating in increased solubility of CFPH and enhanced susceptibility to proteolytic digestive enzymes vis-à-vis its digestibility and utilization as the growth substrate.

\section{Conclusion}

Results on data generated in this study, alkaline hydrolyzed chicken feather protein hydrolysate exhibited excellent antioxidant property through its DPPH scavenging activity, iron-reducing property and metal ion chelating potential. In addition, significant improvement in the in vitro digestibility of chicken feather protein hydrolysate was demonstrated due to alkaline hydrolysis of the chicken feather. Based on these results, the inclusion of chicken feather hydrolysate in animal feed formulations could be advisable not only to preserve the integrity of the feedstuff but also to enhance the functional attributes of the feed as well as an additional source of essential nutrients.

\section{Conflict of Interest}

The authors declare no conflict of interest.

\section{Acknowledgments}

Authors wish to acknowledge the Management of Landmark University Commercial Farms for access to the slaughterhouse.

\section{References}

Akpor, O.B., Jemirieyigbe, E.D. and Oluba, O.M. (2018). Comparative decolouration of crystal violet dye using chicken feather fibre, chemical oxidation and bacterial cells. Journal of Environmental Science and Technology, 11(5), 246-253. https:// doi.org/10.3923/jest.2018.246.253

Akpor, O.B., Odesola, D.E., Thomas, R.E. and Oluba, O.M. (2019). Chicken feather hydrolysate as alternative peptone source for microbial cultivation. F1000Research, 7, 1918. https://doi.org/10.12688/ f1000research.17134.3

Bersuder, P., Hole, M. and Smith, G. (1998). Antioxidants from a heated histidine-glucose model system. I: Investigation of the antioxidant role of 
histidine and isolation of antioxidants by highperformance liquid chromatography. Journal of American Oil and Chemical Society, 75(2), 181-187. https://doi.org/10.1007/s11746-998-0030-y

Boland, M.J., Rae, A.N., Vereijken, J.M., Meuwissen, M.P., Fischer, A.R., van Boekel, M.A., Rutherfurd, S.M., Gruppen, H., Moughan, P.J. and Hendriks, W.H. (2013). The future supply of animal-derived protein for human consumption. Trends in Food Science and Technology, 29(1), 62-73. https:// doi.org/10.1016/j.tifs.2012.07.002

Carocho, M. and Ferreira, I.C. (2013). A review on antioxidants, prooxidants and related controversy: natural and synthetic compounds, screening and analysis methodologies and future perspectives. Food and Chemical Toxicology, 51, 15-25. https:// doi.org/10.1016/j.fct.2012.09.021

Chan, K.M., Decker, E.A. and Feustman, C. (1994). Endogenous skeletal muscle antioxidants. Critical Reviews in Food Science and Nutrition, 34(4), 403426. https://doi.org/10.1080/10408399409527669

Ebrahimzadeh, M.A., Pourmorad, F. and Bekhradnia, A.R. (2008). Iron chelating activity, phenol and flavonoid content of some medicinal plants from Iran. African Journal of Biotechnology, 7(18), 31883192.

Elias, R.J., Kellerby, S.S. and Decker, E.A. (2008). Antioxidant activity of proteins and peptides. Critical Reviews in Food Science and Nutrition, 48 (5), 430-441. https:// doi.org/10.1080/10408390701425615

Fakhfakh, N., Ktari, N., Haddar, A., Mnif, I.H., Dahmen, I. and Nasri, M. (2011). Total solubilisation of the chicken feathers by fermentation with a keratinolytic bacterium, Bacillus pumilusA1, and the production of protein hydrolysate with high antioxidative activity. Process Biochemistry, 46(9), 1731-1737. https://doi.org/10.1016/j.procbio.2011.05.023

Fakhfakh, N., Ktari, N., Siala, R. and Nasri, M. (2013). Wool-waste valorization: production of protein hydrolysate with high antioxidative potential by fermentation with a new keratinolytic bacterium, Bacillus pumilus A1. Journal of Applied Microbiology, 115(2), 424-433. https:// doi.org/10.1111/jam.12246

Hou, Y., Wu, Z., Dai, Z., Wang, G. and Wu, G. (2017). Protein hydrolysates in animal nutrition: industrial production, bioactive peptides, and functional significance. Journal of Animal Science and Biotechnology, 8(1), 24. https://doi.org/10.1186/ s40104-017-0153-9

Jayathilakan, K., Sultana, K., Radhakrishna, K. and
Bawa, A.S. (2012). Utilization of byproducts and waste materials from meat, poultry and fish processing industries: a review. Journal of Food Science and Technology, 49(3), 278-293. https:// doi.org/10.1007/s13197-011-0290-7

Je, J.Y., Qian, Z.J. and Kim, S.K. (2007). Antioxidant peptide isolated from muscle protein of bullfrog, Rana catesbeiana Shaw. Journal of Medicinal Food, 10(3), 401-407. https://doi.org/10.1089/jmf.2006.169

Kanner, J. (2007). Dietary advanced lipid oxidation endproducts are risk factors to human health. Molecular Nutrition and Food Research, 51(9), 1094 -1101. https://doi.org/10.1002/mnfr.200600303

Lasekan, A., Bakar, F.A. and Hashim, D. (2013). Potential of chicken by-products as sources of useful biological resources. Waste management, 33(3), 552565. https://doi.org/10.1016/j.wasman.2012.08.001

Manjula, S. and John, E. (1991). Biochemical changes and in vitro protein digestibility of the endosperm of germinating of Dolichoslablab. Journal of the Science of Food and Agriculture, 55(4), 529-538. https://doi.org/10.1002/jsfa.2740550405

Ohba, R., Deguchi, T., Kishikawa, M., Arsyad, F., Morimura, S. and Kida, K. (2003). Physiological functions of enzymatic hydrolysates of collagen or keratin contained in livestock and fish waste. Food Science and Technology Research, 9(1), 91-93. https://doi.org/10.3136/fstr.9.91

Onifade, A.A., Al-Sane, N.A., Al-Musallam, A.A. and Al-Zarban, S. (1998). A review: potentials for biotechnological applications of keratin-degrading microorganisms and their enzymes for nutritional improvement of feathers and other keratins as livestock feed resources. Bioresource Technology, 66(1), 1-11. https://doi.org/10.1016/S0960-8524(98) 00033-9

Ravindran, V., Hew, L.I., Ravindran, G. and Bryden, W.L. (2005). Apparent ileal digestibility of amino acids in dietary ingredients for broiler chickens. Animal Science, 81(1), 85-97. https:// doi.org/10.1079/ASC42240085

Saiga, A.I., Tanabe, S. and Nishimura, T. (2003). Antioxidant activity of peptides obtained from porcine myofibrillar proteins by protease treatment. Journal of Agriculture and Food Chemistry, 51(12), 3661-3667. https://doi.org/10.1021/jf021156g

Steiner, R.J., Kellems, R.O. and Church, D.C. (1983). Feather and hair meals for ruminants. IV. Effects of chemical treatments of feathers and processing time on digestibility. Journal of Animal Science, 57(2), 495-502. https://doi.org/10.2527/jas1983.572495x

Tang, X., He, Z., Dai, Y., Xiong, Y.L., Xie, M. and 
Chen, J. (2009). Peptide fractionation and free radical scavenging activity of zein hydrolysate. Journal of Agriculture and Food Chemistry, 58(1), 587-593. https://doi.org/10.1021/jf9028656

Tesfaye, T., Sithole, B., Ramjugernath, D. and Chunilall, V. (2017). Valorisation of chicken feathers: characterisation of physical properties and morphological structure. Journal of Cleaner Production, 149, 349-365. https://doi.org/10.1016/ j.jclepro.2017.02.112

Zaghloul, T.I., Embaby, A.M. and Elmahdy, A.R. (2011). Biodegradation of chicken feathers waste directed by Bacillus subtilis recombinant cells: Scaling up in a laboratory scale fermentor. Bioresource Technology, 102(3), 2387-2393. https:// doi.org/10.1016/j.biortech.2010.10.106

Zhu, G.Y., Zhu, X., Wan, X.L., Fan, Q., Ma, Y.H., Qian, J., Liu, X.-L., Shen, Y.J. and Jiang, J.-H. (2010). Hydrolysis technology and kinetics of poultry waste to produce amino acids in subcritical water. Journal of Analytical and Applied Pyrolysis, 88(2), 187-191. https://doi.org/10.1016/j.jaap.2010.04.005 